\title{
PIJAT BAYI DAPAT MENINGKATKAN BERAT BADAN BAYI
}

\author{
Bunga Tiara Carolin ${ }^{1}$, Siti Syamsiah², Mita Mauliah Khasri ${ }^{3}$ \\ 1Program Studi Kebidanan, Fakultas IImu Kesehatan, Universitas Nasional Jakarta \\ email: bunga.tiara@civitas.unas.ac.id \\ 2Program Studi Kebidanan, Fakultas IImu Kesehatan, Universitas Nasional Jakarta \\ email: sitisyamsiah09@gmail.com \\ 3Program Studi Kebidanan, Fakultas IImu Kesehatan, Universitas Nasional Jakarta \\ email: mitamauliah1995@gmail.com
}

\begin{abstract}
Background: Weight problems in babies are very sensitive, as evidenced by World Health Organization (WHO) data stating the incidence of infant weight in the world is still below the standard of more than $5 \%$ with the prevalence of underweigh in southeast asia 26.9\% (WHO, 2017). One of the efforts to optimize weight gain in infants in addition to the nutrition provided by the women, one of which needs to be the stimulation of stimuli or commonly known as baby massage.

Puprose: This study aims to determine the effect of infant massage on infant weight in the Alanda Care working area of Pangkalpinang City, Bangka Belitung Province.

Methods: The study used the Quasy Experiment method with Two Group pretest and postest Design. The population in this study is infants aged 2-5 months. The sample in this study are 30 respondens. Data were analyzed using paired t-test and Independen T-Test.

Results: The results showed that there were 793 grams of infant weight in the intervention group and 400 grams in the control group. There were differences in the results of the pretest and posttest in each of the intervention groups $(p=0,000)$ and the control group $(p=0,000)$ and there is an effect of baby massage on baby weight $(p=0,000)$.

Conclusion: Although both of them gained weight in the intervention group and the control group, the weight gain in the intervention group almost doubled compared to the control group and there was also the effect of massage on baby weight.

Suggestion: It is expected that health workers can provide education about baby massage and its benefits to parents, especially those who have babies, so that public participation in the health sector can be increased
\end{abstract}

Keywords: Baby, Massage, Weight

\section{ABSTRAK}

Latar Belakang: Permasalahan berat badan pada bayi sangatlah sensitif, terbukti dari data World Health Organization (WHO) tahun 2017 menyatakan angka kejadian berat badan bayi di dunia masih di bawah standar yaitu lebih dari $5 \%$ dengan prevalensi underweigh di asia tenggara $26,9 \%$. Salah satu upaya untuk mengoptimalkan berat badan pada bayi di samping nutrisi yang diberikan oleh ibu, salah satunya perlu juga adanya rangsangan stimulus atau yang biasa di kenal dengan pijat bayi.

Tujuan: Untuk mengetahui pengaruh pijat bayi terhadap berat badan bayi di wilayah kerja Alanda Care Kota Pangkalpinang Provinsi Bangka Belitung.

Metode: Penelitian menggunakan metode Quasy Experimen dengan Two Group pretest and postest Design. Populasi dalam penelitian ini adalah seluruh bayi 2-5 bulan. Sampel dalam penelitian ini berjumlah 30 responden yang dibagi menjadi dari 2 kelompok. Data dianalisa dengan Paired $t$ test dan Independen T-Test.

Hasil: Hasil penelitian menunjukkan bahwa ada kenaikan berat badan bayi pada kelompok intervensi sebanyak 793 gram dan pada kelompok kontrol sebanyak $400 \mathrm{gram}$. Terdapat perbedaan hasil pretest dan posttest pada masing-masing kelompok intervensi $(p=0,000)$ dan kontrol $(p=0,000)$ dan terdapat pengaruh pemberian pijit bayi terhadap berat badan bayi $(p=0,000)$.

Kesimpulan: Walaupun sama-sama terdapat kenaikan berat badan bayi pada kelompok intervensi maupun kelompok kontrol, tetapi kenaikannya berat pada kelompok intervensi mencapai hampir dua kali lipat daripada kelompok control dan juga ada pengaruh pijat terhadap berat badan bayi. 
Saran: Diharapkan bagi petugas kesehatan dapat memberikan pendidikan tentang pijat bayi dan manfaatnya kepada para orangtua terutama yang memiliki bayi agar peran serta masyarakat di bidang kesehatan dapat meningkat.

Kata Kunci: Bayi, Pijat, Berat Badan

\section{PENDAHULUAN}

Setiap bayi diharapkan dapat tumbuh dengan optimal dan untuk mencapai pertumbuhan yang optimal pada bayi merupakan hasil interaksi berbagai faktor yang saling berkaitan, yaitu faktor genetik, lingkungan dan perilaku, serta rangsangan atau stimulasi yang berguna (Soetjiningsih, 2017). Salah satu indikator terpenting dalam menilai pertumbuhan pada bayi merupakan dengan menilai berat badan bayi (Astriana, \& Suryani, 2017). Berat badan merupakan ukuran antropometri yang terpenting, yang dipakai pada setiap kesempatan memeriksa kesehatan bayi pada semua kelompok umur (Soetjiningsih, 2017). Sehingga bayi yang dikatakan sehat ditandai dengan bertambahnya berat badan.

Permasalahan berat badan pada bayi sangatlah sensitif, terbukti dari data World Health Organization (WHO) menyatakan angka kejadian berat badan bayi di dunia masih di bawah standar yaitu lebih dari $5 \%$ dengan prevalensi underweigh di asia tenggara 26,9\%. Sedangkan prevalensi underweigh di dunia secara global sebesar 14\% (WHO, 2017). Kenaikan berat badan juga sangat berkesinambungan dengan asupan nutrisi yang diberikan ibu, menurut Profil Kesehatan Indonesia pada tahun 2017 presentase status gizi yang disebabkan oleh berat badan pada usia (0-23 bulan) presentase gizi kurang sebesar $11,3 \%$. Sedangkan dibandingkan pada tahun 2018 presentase kasus gizi kurang sebesar $11,4 \%$. Hal ini menunjukkan terjadinya peningkatan status gizi kurang pada tahun 2017 hingga tahun 2018 (Profil Kesehatan Indonesia 2018). Menurut laporan data dari Provinsi Bangka Belitung mengenai status gizi berdasarkan berat badan menyatakan pada tahun 2017 usia (0-23 bulan) presentase gizi kurang sebesar $(13,0 \%)$ dan pada tahun 2018 presentase gizi kurang (13,6\%) (Profil Kesehatan Bangka Belitung 2018). Hal ini menunjukkan adanya peningkatan status gizi kurang berdasarkan berat badan yang terjadi pada tahun 2017 hingga tahun 2018.

Meningkatnya gizi kurang pada bayi disebabkan oleh berbagai faktor diantaranya pemenuhan nutrisi pada bayi yang kurang, ke tidak tahunya orang tua tentang pemberian asi kepada bayinya, serta kebersihan lingkungan yang rendah.
Hal ini dapat berdampak pada pertumbuhan bayi terhambat dan salah satunya berdampak pada berat badan bayi yang tidak sesuai dengan usianya. Maka, ini merupakan permasalahan yang harus diperhatikan oleh tenaga kesehatan untuk mencegah bertambahnya gizi kurang yang berdampak pada berat badan bayi yang tidak sesuai dengan usianya serta tidak berkelanjutan meningkat ke gizi buruk (Kemenkes, 2018).

Upaya yang dapat dilakukan dalam mengoptimalkan berat badan pada bayi di samping nutrisi yang diberikan oleh ibu dan salah satu cara lain perlu adanya rangsangan stimulus atau yang biasa di kenal dengan pijat bayi. Pijat merupakan salah satu metode pengobatan tertua di dunia. Pijat meliputi seni perawatan kesehatan dan pengobatan yang mampu melemaskan sendi yang terlalu kaku dan menyatukan organ tubuh dengan berupa sentuhan. Dengan adanya sentuhan pemijatan terhadap jaringan otot peredaran darah, dapat meningkatkan jaringan otot ataupun posisi otot dapat dipulihkan dan diperbaiki sehingga dapat meningkatkan fungsi-fungsi organ tubuh dengan sebaik-baiknya (Roesli, 2016). Pada saat dilakukan pemijatan bayi tentunya banyak memberikan manfaat bagi orangtua ketahui khususnya para ibu. Pijatan atau sentuhan kepada bayi memberikan manfaat yaitu membuat bayi merasa tenang, meningkatkan kualitas tidur bayi, mengajari bayi sejak dini mengenai bagian tubuh dan merangsang nafsu makan bayi (Julianti, 2018). Salah satu manfaat dari pemijatan bayi yaitu merangsang nafsu makan bayi. dengan dilakukan pemijatan bayi merangsang aktivitas nervus vagus, di mana saraf ini (saraf otak ke-10) yang akan menyebabkan peningkatan kadar enzim penyerapan gastrin dan insulin, sehingga penyerapan makanan akan lebih baik serta meningkatkan persitaltik usus dan pengosongan lambung meningkat yang dapat merangsang nafsu makan bayi (Roesli, 2016).

Menurut Jabraeile, et al (2016) bebarapa penelitian telah menunjukan bahwa $31-49 \%$ pijat bayi pada premature dapat meningkatkan 31$49 \%$ berat badan yang diikuti juga dengan peningkatan besar lingkar kepala dan tinggi badan. Hasil penelitian yang dilakukan Astriana, \& Suryani (2017), pada bayi cukup bulan usia 1-6 bulan dipijat 15 menit, dalam dua kali seminggu selama enam 
minggu, akan mengalami kenaikan berat badan lebih baik dari pada bayi yang tidak dipijat. Namun hasil ini tidak sejalan dengan penelitian Fauziyah \& Wijayanti (2018) yang menyatakan bahwa tidak terdapat pengaruh pemberian pijat bayi terhadap perubahan berat badan bayi. Adanya kesenjangan diantara kedua penelitian inilah membuat peneliti tertarik untuk melakukan penelitian apakah ada pengaruh pemberian pijat bayi terhadap berat badan bayi di Alanda Care Kota Pangkalpinang Provinsi Bangka Belitung.

\section{METODE PENELITIAN}

Metode penelitian ini adalah Quasy Eksperimen dengan pendekatan Two Group pretest and postest Design. Lokasi penelitian berada di Alanda Care Kota Pangkalpinang Provinsi Bangka Belitung. Waktu penelitian dilakukan pada Desember 2019 - Januari 2020. Populasi dalam penelitian ini adalah seluruh bayi 2-5 bulan sebanyak 46 bayi. Pengambilan sampel dilakukan dengan menggunakan Proporsive Sampling, dimana pengambilan sampel yang berdasarkan atas suatu pertimbangan tertentu sehingga sampel dalam penelitian ini sebanyak 30 responden di mana 15 responden kelompok intervensi dan 15 responden kelompok kontrol. Langkah pengambilan data dimulai dengan melakukan studi pendahuluan, mengurus perizinan, memberikan lembar informed consent kepada orang tua bayi yang dijadikan sampel, melakukan penimbangan sebelum dilakukan pemijitan, kemudian dilakukan prosedur pemijatan dengan cara pemijatan dilakukan $2 x$ seminggu dengan durasi 15 menit yang dilakukan selama 30 hari, lalu setelah prosedur pemijitan tersebut selesai dilakukan penimbangan kembali dan terakhir dilakukan pengolahan data Instrumen Penelitian menggunakan lembar observasi. Bahan yang pakai dalam penelitian adalah minyak zaitun dan alat yang digunakan adalah timbangan untuk bayi. Pada hasil homogenitas didapatkan data homogen dan pada uji normalitas dengan cara melihat nilai skwiness dan kurtosis didapatkan data berdistribusi normal sehingga analisis data menggunakan Paired $t$ test dan Independen T-Test.

\section{HASIL PENELITIAN}

Tabel 1.

Distribusi Frekuensi Karakteristik Responden

Berdasarkan Jenis Kelamin dan Usia pada

Kelompok Intervensi dan kelompok control

\begin{tabular}{lcccc}
\hline \multirow{2}{*}{ Kriteria } & \multicolumn{4}{c}{ Kelompok } \\
\cline { 2 - 5 } & \multicolumn{2}{c}{ Intervensi } & \multicolumn{2}{c}{ Kontrol } \\
\cline { 2 - 5 } & $(\mathrm{F})$ & $(\%)$ & $(\mathrm{F})$ & $(\%)$ \\
\hline Jenis kelamin & & & & \\
Laki-laki & 7 & $46,7 \%$ & 9 & $60 \%$ \\
Perempuan & 8 & $53,3 \%$ & 6 & $40 \%$ \\
Usia & & & & \\
2 bulan & 6 & $40 \%$ & 4 & $26,7 \%$ \\
3 bulan & 7 & $46,7 \%$ & 5 & $33,3 \%$ \\
4 bulan & 1 & $6,7 \%$ & 4 & $26,7 \%$ \\
5 bulan & 1 & $6,7 \%$ & 2 & $13,3 \%$ \\
\hline
\end{tabular}

Tabel 1 menunjukkan bahwa dari 15 responden pada kelompok intervensi mayoritas berjenis kelamin perempuan dengan persentase $53,3 \%$. Sedangkan dari 15 responden pada kelompok kontrol mayoritas berjenis kelamin lakilaki dengan persentase $60 \%$. Pada tabel di atas juga menunjukkan bahwa dari 15 responden pada kelompok intervensi mayoritas berumur 3 bulan dengan persentase $46,7 \%$ dengan rata-rata berat badan bayi kisaran rata-rata berat badan normal (4,5-5,4 gram). Sedangkan dari 15 responden pada kelompok kontrol mayoritas berumur 3 bulan dengan persentase $33.3 \%$ dengan kisaran rata-rata berat normal (4,5-5,4 gram).

Tabel 2.

Berat Badan Bayi Pre-Test Dan Post-Test Pada masing-Masing Kelompok Intervensi dan Kontrol

\begin{tabular}{lccccc}
\hline \multicolumn{1}{c}{ Kelompok } & $\mathrm{N}$ & Mean & St Deviation & St. Error & P Value \\
\hline Intervensi & & & & & \\
Pre-test & 15 & 4993 & 411,3 & 106,2 & 0,000 \\
Post-test & & 5786 & 456,4 & 117,8 & \\
Kontrol & & & & & \\
Pre-test & \multirow{2}{*}{15} & 5260 & 516,5 & 133,3 & \multirow{2}{*}{0,000} \\
Post-test & & 5660 & 550,0 & 142,0 & \\
\hline
\end{tabular}

Berdasarkan tabel 2 berat badan sebelum diberikan intervensi adalah 4993 gram. Sedangkan untuk nilai post-test diperoleh nilai rata-rata sebesar 5786 gram. Selisih berat badan bayi sebanyak 793 
gram. Pada kelompok intervensi juga didapatkan $p$ value 0,000 yang artinya terdapat perbedaan berat badan bayi sebelum dan sesudah diberikan pijit bayi. Pada tabel 2 juga menunjukan bahwa hasil nilai pre-test pada kelompok kontrol rata-rata sebesar $5260 \mathrm{gram}$. Sedangkan untuk nilai post-test diperoleh nilai rata-rata sebesar 5660 gram. Selisih berat badan bayi sebanyak 400 gram. Pada kelompok kontrol juga didapatkan $p$ value 0,000 yang artinya terdapat perbedaan berat badan bayi sebelum dan sesudah diberikan pijit bayi.

Tabel 3.

Perbedaan rata-rata berat badan bayi Kelompok Post-test Intervensi dan Kontrol

\begin{tabular}{lcccccc}
\hline \multicolumn{1}{c}{ Kelompok } & N & Mean & St Deviation & St. Error & t & P Value \\
\hline Post-test Intervensi & 15 & 5786 & 456,4 & 117,8 & 0,733 & \multirow{2}{*}{0,000} \\
Post-test Kontrol & 15 & 5660 & 550,0 & 142,0 & 0,733 & \multirow{2}{*}{} \\
\hline
\end{tabular}

Tabel 3 menunjukan bahwa dari jumlah sampel 15 responden pada post-test kelompok kontrol nilai rata-rata berat badan bayi yaitu 5786 gram dengan standar deviensi 456,4 sedangkan untuk kelompok eksperimen post-test nilai rata-rata berat badan bayi yaitu 5660 gram dengan standar deviensi 550,0. Hasil uji statistik independent sampel test didapatkan nilai $\mathrm{p}=0,000<0,05$ yang artinya $\mathrm{Ho}$ ditolah dan $\mathrm{Ha}$ diterima, sehingga terdapat perbedaan yang signifikan rata-rata kenaikan berat badan bayi pada kelompok eksperimen dengan kelompok kontrol yang artinya ada pengaruh pijat bayi terhadap berat badan bayi.

\section{PEMBAHASAN}

Pijat bayi adalah memberikan sentuhan pada tubuh bayi atau anak yang bermanfaat untuk menstimulus tumbuh kembang bayi dan sebagai salah satu cara untuk mengungkapkan kasih sayang orangtua terhadap anaknya (Kalsum, 2014). Pijat bayi biasa disebut dengan stimulus touch seperti yang diungkapkan oleh Dewi (2016), bahwa pijat bayi dapat diartikan sebagai sentuhan komunikasi yang nyaman antara ibu dan bayi, jadi pijat bayi ini merupakan suatu pengungkapan rasa kasih sayang antara orangtua dengan anak lewat sentuhan pada kulit yang dapat memberikan dampak sanagat luar biasa. Secara teoritis, bayi memang memiliki berat badan yang bervariasi. Peningkatan berat badan bayi pun sangat dipengaruhi oleh berbagai faktor baik internal maupun eksternal. Karena itu, setiap bayi akan memiliki berat badan yang bervariasi tergantung dari faktor-faktor tersebut. Dalam periode tertentu terdapat adanya masa percepatan atau masa perlambatan, serta laju tumbuh kembang yang berlainan diantara organ-organ (Soetjiningsih, 2017).

Berdasarkan hasil penelitian di Alanda Care Kota Pangkalpinang Provinsi Bangka Belitung didapatkan bahwa responden pada kelompok intervensi mayoritas berjenis kelamin perempuan responden pada kelompok kontrol mayoritas berjenis kelamin laki-laki. Penelitian juga menunjukkan bahwa baik pada kelompok intervensi maupun kontrol mayoritas responden berumur tiga bulan dengan rata-rata berat badan bayi kisaran rata-rata berat badan normal (4,5-5,4 gram). Dalam hasil penelitian ini walaupun sama-sama terdapat kenaikan berat badan bayi pada kelompok intervensi maupun kelompok kontrol, tetapi kenaikannya berat pada kelompok intervensi mencapai hampir dua kali lipat daripada kelompok kontrol. Hasil penelitian ini sejalan dengan penelitian Handayani \& Rasumawati (2018) bawa berat badan bayi yang dipijat lebih tinggi dibandingkan dengan tidak dipijat. Penelitian krinanto \& Natalia (2019) juga menyatakan bahwa terjadi peningkatan berat badan bayi setelah pijat bayi. Begitu juga dengan penelitian yang di kemukakan oleh Suprianto (2011), yang mengatakan peningkatan berat badan bayi tersebut tentunya sangat dipengaruhi oleh pemberian pijat bayi yang diberikan secara kontiniu. Pada dasarnya bayi yang dipijat akan mengalami peningkatan kadar enzim penyerapan dan insulin sehingga penyerapan terhadap sari makanan pun menjadi lebih baik. Hasilnya, bayi menjadi cepat lapar dan karena itu lebih sering menyusu sehingga meningkatkan produksi ASI.

Kemudian dari hasil uji statistik pada penelitian ini juga didapatkan bahwa terdapat pengaruh pijat bayi terhadap berat badan bayi. Hasil penelitian sejalan penelitian Feronika \& Nasution (2018) bahwa ada pengaruh pijat bayi terhadap berat badan bayi. Penelitan Susila (2018) juga menyatakan bahwa terdapat pengaruh yang signifikan pijat bayi terhadap kenaikan berat badan bayi. Harahap (2019) juga menyatakan ada pengaruh pijat bayi terhadap kenaikan berat badan bayi usia 0-6 bulan, begitupula dengan Carolin, et al (2020) yang mengatakan bahwa ada perbedaan atau pengaruh rata - rata antara hasil kelompok control dan kelompok perlakuan pada bayi yang distimulasi dengan pijat bayi. 
Berdasarkan asumsi peneliti pijat bayi dapat merangsang saraf nervus vagus dimana saraf ini bertaggung jawab untuk menginervasi perut dan paru-paru dan meningkatkan fungsi sensorik dan motorik lambung sehingga membuat lambung kosong lebih cepat dan membuat bayi menjadi lapar sehingga meningkatkan konsumsi ASI. Dengan adanya peningkatan konsumsi ASI maka penyerapan nutrisinya menjadi lebih baik dan dapat meningkatkan berat badan.

\section{SIMPULAN}

Berdasakan hasil penelitian dapat disimpulkan bahwa walaupun sama-sama terdapat kenaikan berat badan bayi pada kelompok intervensi maupun kelompok control, tetapi kenaikannya berat pada kelompok intervensi mencapai hampir dua kali lipat daripada kelompok kontrol. Dari hasil penelitian ini juga dapat disimpulkan bahwa ada pengaruh pijit bayi terhadap berat badan bayi.

\section{SARAN}

Bagi petugas kesehatan dapat memberikan pendidikan tentang pijat bayi dan manfaatnya kepada para orangtua terutama yang memiliki bayi agar peran serta masyarakat di bidang kesehatan dapat meningkat. Bagi Institusi pendidikan dengan adanya hasil penelitian ini dapat dipergunakan untuk dapat berkolaborasi kepada pihak institusi untuk memberikan pembelajaran serta praktik pemijatan bayi kepada mahasiswa.

\section{DAFTAR PUSTAKA}

Astriana, A., \& Suryani, I. L. (2017). Pengaruh Pijat Bayi Terhadap Peningkatan Berat Badan Pada Bayi Di Bps Masnoni Teluk Betung Utara Kota Bandar Lampung. Holistik Jurnal kesehatan, 11(2), 72-76.

Carolin, B. T., Suprihatin., Agustin, C., (2020). Pijat Bayi dapat Menstimulus Peningkatan Berat Badan pada Bayi. Jurnal IImiah kebidanan Indonesia, 10(2), 28-33.

Dewi, S., (2016). Pijat dan Asupan Gizi Tepat. Yogyakarta: Pustaka Baru Pres.

Dinkes Babel., (2017). Provil Kesehatan Babel, Dinas Kesehatan Bangka Belitung, Bangka Belitung

Dinkes Babel., (2018). Provil Kesehatan Babel, Dinas Kesehatan Bangka Belitung, Bangka Belitung

Fauziah, A., \& Wijayanti, H. N. (2018). Pengaruh Pijat Bayi terhadap Kenaikan Berat Badan dan Kualitas Tidur Bayi di Puskesmas Jetis
Yogyakarta. PLACENTUM: Jurnal IImiah Kesehatan dan Aplikasinya, 6(2), 14-19.

Feronika, S., \& Nasution, N. (2018). Pengaruh Pijat Bayi Terhadap Berat Badan Bayi Di Posyandu Flamboyan Taman Lestari Batam. Zona Keperawatan: Program Studi Keperawatan Universitas Batam, 9(1), 59-64.

Handayani, S., \& Rasumawati, R. (2018). Increase Weight Infant With Family Approach Through Massage Therapy. Health Notions, 2(4), 505507.

Harahap, N. (2019). Pijat Bayi Meningkatkan Berat Badan Bayi Usia 0-6 Bulan. Jurnal Kesehatan Prima, 13(2), 99-107.

Jabraeile, M., Rasooly, A. S., Farshi, M. R., \& Malakouti, J. (2016). Effect of olive oil massage on weight gain in preterm infants: A randomized controlled clinical trial. Nigerian medical journal: journal of the Nigeria Medical Association, 57(3), 160.

Julianti., (2018)., Rahasia Baby Spa, Rumah Sehat Bunda, Depok, p; 14-21.

Kalsum, U. (2014). Peningkatan Berat Badan Bayi Melalui Pemijatan. Jurnal Keperawatan Indonesia, 17(1), 25-29.

Kemenkes R.I., (2017), Data dan Informasi Profil Kesehatan Indonesia, Kementerian Kesehatan Republik Indonesia, Jakarta.

Kemenkes R.I., (2018), Data dan Informasi Profil Kesehatan Indonesia, Kementerian Kesehatan Republik Indonesia, Jakarta.

Krisnanto, P. D., \& Natalia, L. (2019). The Effectiveness Of Baby Swimming And Baby Massage In Improving Baby Weight. In Proceeding International Conference (Vol. 1, No. 1, pp. 77-80).

Roesli, U., (2016). Pedoman Pijat Bayi, Jakarta: Trubus Angriwidya.

Soetjiningsih, (2016). Tumbuh Kembang Anak, Surabaya: EGC.

Suprianto., (2011). Pijat Bayi Meningkatkan Berat Badan Bayi: Jurnal Ksehatan, 5(1), 1-5.

Suryani, I.L., (2017). Pengaruh Pijat Bayi terhadap Peningkatan Berat Badan Bayi di BPS Masnoni Teluk Betung Utara Kota Bandar Lampung: Holistik Jurnal Kesehatan, 11(2), 1-10.

Susila, I. (2018). Pengaruh Teknik Pijat Bayi Terhadap Kenaikan Berat Badan Bayi Usia 0-7 Bulan di BPS Ny. Aida Hartatik Desa Dlanggu Kecamatan Deket Kabupaten Lamongan. Jurnal Midpro, 9(2), 10.

WHO., (2017), Level and Trends in Child Malnutrition,https://data.worldbank.org, diakses $\quad 10 \quad$ September 2019. 